\title{
Arizona: The Political Ecology of a Desert State
}

\author{
Thomas E. Sheridan
}

In 1976, Arizona business leaders commissioned Herman Kahn's Hudson Institute to peer into its crystal ball and divine Arizona's future. Entitled Arizona Tomorrow, the report called Arizona "the development prototype for post-industrial society." During the nineteenth century, many people perceived Arizona as a desert wasteland on the route to California: hot, parched, and desolate. But in the final half of the twentieth century, the state had managed to redefine "the very term desert." Desert, Arizona style, now meant "an appealing landscape, an attractive place to live, and a new kind of adult playground." According to Arizona Tomorrow, "Desert living with air conditioning, water fountains, swimming pools--getting back to nature with a motorized houseboat on Lake Powell (itself a man-made lake), and going for an ocean swim in a man-made ocean are all contemporary examples of the marriage between life-style and technology" (P. Wiley and R. Gottlieb 1982:175).

It was a futuristic vision of paradise in an arid land, with "technology" the handmaiden of "life -style" and the old extractive order banished by the economic miracle of the Great Transition. Rust Belt industrialism had given way to Sunbelt postindustrialism. There were no undocumented Mexican workers living in citrus groves and drinking from irrigation canals; no striking copper miners forced to take minimum-wage jobs; no unemployed Indians hauling uranium-contaminated water in the backs of old pickup trucks. Instead, everyone was a young upwardly mobile urban professional with plenty of leisure time to pursue Arizona's beguiling pleasures. Water images permeated this Xanadu. Redefining the desert meant pouring massive amounts of water onto it. A desert with plenty of water was an oxymoron futurists and their developer patrons promoted without a trace of irony.

And whether the water was used for the old extractive purposes or for creating this bright, wet new play world, the vision assumed an endless flow. It also presupposed plenty of cheap energy to run the airconditioners, fill the swimming pools, power the houseboats, and keep the man-made waves cresting. Water and energy were flip sides of the same coin--the currency that bankrolled the postwar boom and made the down payment on the postindustrial future. One without the other was inconceivable and unusable. Gravity caused runoff from the Rockies to surge down the Colorado River and rainfall from thousands of years of desert storms to percolate through the alluvium to create underground aquifers. Whether with pumps, canals, or dams, Arizona history has been one long reversal of gravity. In the modern West, water flows uphill toward money. Cheap energy makes that astonishing feat of legerdemain possible.

It also gives us the illusion that we have freed ourselves from most environmental constraints. We are living at a time when the relationships between that fundamental cultural dichotomy--culture and nature -- are increasingly ambiguous. For most of human history, nature was a collection of forces to be propitiated and feared. Two centuries ago, however, the relationship began to change as Western industrial civilization harnessed steam, electricity, fossil fuels, and vaccines. People boasted about triumphing over nature 
as distances were collapsed and the terrifying threats of flood, drought, and pestilence were reduced. Today, we even contemplate the "End of Nature," confident of our ability to control natural forces and convert them into commodities. We debate "multiple use" and consciously set aside refuges where nature can be protected from our onslaught. In the words of Arizona Tomorrow, we have transformed the desert into an "adult playground," vanquishing heat, aridity, and all the other ancient constraints on endless growth.

During the last decade and a half, that illusion of freedom from the natural has seeped into cultural anthropology as well. Cultural ecology has been dismissed as vulgar materialism or just another manifestation of structural functionalism. Meanwhile, political economists battle cultural theorists with remarkably little reference to ecological anthropology.

A good example is William Roseberry's (1989) incisive collection of essays entitled Anthropologies and Histories, which makes only one reference to cultural ecology. Analyzing Marx and Engels' The German Ideology, Roseberry advocates "a materialism that starts not with nature or with a postulated economic structure but with a human population. It begins not with matter but with the social, conceived as material" (1989:38). Then he calls for an "active" materialism. "People enter into definite relations with others and with nature, but as they enter into those relations they transform both nature and themselves," Roseberry contends (1989:38). "Nature and the social world, then, are always socially constructed, historical."

Few ecological anthropologists would argue with the first part of that statement. Nature and society engage in constant interaction because they cannot really be isolated from one another. As historian William Cronon (1991:xix) notes in Nature's Metropolis: Chicago and the Great West, "the boundary between human and nonhuman, natural and unnatural, is profoundly problematic." Cronon goes on to say, "Just as our own lives continue to be embedded in a web of natural relationships, nothing in nature remains untouched by the web of human relationships that constitute our common history" (Cronon 1991:19). Consciously or unconsciously, people have shaped vegetation communities, animal communities, and disease environments from prehistoric times to the present. Now we may even be shaping global patterns of climate. Environmental determinism, most of us agree, is far too crude a model to capture the interplay between nature and culture.

But Roseberry and other political economists are less interested in the nexus between the natural and the social than between the social and the cultural. Like many Marxist theorists, Roseberry subsumes nature under the "material circumstances" of people's lives, holding it more or less constant while he does battle with Geertz and Sahlins over the relationships between material conditions and symbols and ideas. "We have begun with culture, turned to history, and ended with politics," he concludes (1989:232). "My purpose in this book has been to make the political footnote an integral part of the cultural text, to see the politics in culture" (1989:232).

Roseberry's trajectory does not include the natural environment. I would therefore like to paraphrase him by saying that it is also necessary to make the ecological footnote an integral part of political economy, to see nature in political struggle. Furthermore, I want to advocate an active materialism that incorporates an active nature, not the singularly inert nature of most Marxian theory. The historical processes of commodification generated by capitalism have alienated both human labor and natural resources from their wider social and ecological fields. But while a great deal of attention has been paid to how humans accommodate, resist, or manipulate this process, nature, the ultimate other, 
remains trapped in conceptual limbo--passive rather than active, reactor rather than actor, background rather than foreground, feminine rather than the gendered and ungendered collection of beings and forces that it is. I believe this leads to a materialism that is dangerously incomplete and one-sided.

More to the point, nature has a way of intruding into our consciousnesses and imprinting itself upon our bodies in novel and unexpected ways. As the Earth First! bumper sticker says, "Nature Bats Last." Sometimes the changing boundaries between the cultural and the natural benefit human beings, and other times they unleash new plagues. Viruses circulating in animal hosts suddenly explode into human populations as those animals become domesticated or as more and more people push into their environments. Climatic fluctuations become more extreme as human-induced changes in the earth's atmosphere intensify. To bring the discussion back to Arizona, engineers and politicians constructed a river that flowed an average of 16,400,000 acre-feet a year during the 1920s, when they were forging the Colorado River Compact (N. Hundley 1975). The Colorado River spent the next seventy years deconstructing that hydrological phantasm. Our constructions of nature are always partial and always incomplete. The social construction of nature does not necessarily imply its social control.

To restore some balance, at least in my own work, I employ an emerging research strategy called political ecology. I borrowed the term from Eric Wolf, who used it in an apt but off-handed fashion in Europe and the People Without History (1982). At the time I first read the book, I was struggling to make sense of the politics of resource control in the municipio of Cucurpe, Sonora, the Mexican state that borders Arizona (T. Sheridan 1988). ${ }^{1}$ I realized the limitations of conventional cultural ecology, because Cucurpe, plugged into a transnational livestock industry, was clearly affected by regional, national,

1. Cucurpe is a large municipio (1,789 square $\mathrm{km})$ with a small population of ranchers and farmers. Most of it is semi-arid Sonoran Desert drained by the San Miguel River and its tributaries. The fundamental natural constraints of climate and topography have conspired to divide Cucurpe into three major resource zones: (1) the floodplain, where milpa, or irrigated agriculture, takes place; (2) the side canyons of the San Miguel, where tempo$\mathrm{ral}$, or runoff dependent agriculture occurs; and (3) the desert and oak uplands, where cattle, horses, and goats graze.

And because the San Miguel is an intermittent stream, many stretches ofthe floodplain don't have enough flowing surface water to support irrigated agriculture. Less than one percent of the municipio is cultivated, making arable land a scarce and contested resource. In 1980-81, only 42 percent of the resident households in the municipio possessed milpas. Of those households, 84 percent held milpas that were five hectares (ha) or smaller. Those fields are intensively cultivated, yet no one has enough land to specialize in agriculture or to engage in commercial agriculture. With few exceptions, Cucurpeños consume the yields of their own fields.

Nevertheless, irrigated agriculture is the foundation of Cucurpe's mixed agropastoralist economy. The primary cash product of the municipio is cattle, particularly male feeder calves which are exported to the UnitedStates. Because the range is severely overgrazed, however, supplementary feed must be provided, and most of that feed is raised on Cucurpe milpas and temporales. The sale of livestock provides most family income, but it is nearly impossible to survive as a stockraiser without arable land. 
and global forces. At the same time, however, world systems analysis and other approaches from political economy often ignored the local ecological and demographic factors that also shaped the struggle over land and water in peasant societies. The literature devoted much-needed attention to the relationships between peasants and the state and peasants and the world economy with its international division of labor. But that same literature paid very little attention to even more pressing daily concerns of small ranchers and farmers--how to make a living from a hard, dry land. Consequently, I tried to wed cultural ecology and political economy in a concrete and pragmatic fashion to explore both the local and extralocal forces that influenced the politics of resource control in the municipio.

In the process, I discovered that those politics could not be understood without understanding the nature of the resources being contested, particularly arable land, grazing land, and irrigation water. Within Cucurpe's agropastoralist economy, households need access to all three of those natural resources. Moreover, given the level of technology, those resources impose certain constraints on the ways in which they can be exploited. Because arable land is limited and fields are small, households possess the capital and labor power to cultivate that land without engaging in cooperative labor or requiring access to large sources of credit. Arable land is therefore controlled at the household level, and many milpas and temporales have been passed down from generation to generation within the same family.

Many households, on the other hand, do not have the capital to purchase the amount of grazing land (agostadero) necessary to support livestock in the Sonoran Desert. Consequently, stockraisers need access to large tracts of land upon which their animals can roam in search of fodder and water. Private ranchers, most of whom live outside the municipio, control about 80 percent of the municipio. Small peasant rancher-farmers, in contrast, have joined together to form three corporate communities--two comunidades and one ejido -- to gain access to rangeland. That range is open and controlled by the corporate communities, two of which have probably been in existence since the Spanish colonial period, when Cucurpe was a Jesuit and then a Franciscan mission.

The same households who belong to the corporate communities also belong to local water-users' associations called comunes de agua. These associations control springs in the San Miguel River, or its tributaries, that feed the small gravity-flow canal systems (acequias) that irrigated floodplain fields. Each association elects one of its members water judge (juez de agua) in January. The water judge organizes communal work parties to clean and repair the diversion weirs and canals, and regulates irrigation turns. Dating back to Moorish and Roman Spain, comunes de agua like those found in Cucurpe can also be found in other areas of Spanish America including northern New Mexico where subsistence agriculture still takes place (M. Meyer 1984; S. Crawford 1988).

Land tenure and resource control in Cucurpe support Robert Netting's hypotheses $(1976,1981)$ about private versus common property in peasant communities: resources such as floodplain land that can be effectively used and intensified in small, fixed amounts are privately owned; resources whose frequency and dependability of exploitation are low, such as desert rangeland, are held by the corporate communities themselves. In a very real sense, the nature of the resource determines the social organization of production as much as the political and economic webs in which the Cucurpeños are enmeshed. Those relationships are always mediated by technology and history, but the natural environment is not a blank slate upon which different cultures write different scripts. Regional climatic patterns, the hydrology of the San Miguel River, and the floral characteristics of the 
Sonoran Desert are just three of the natural variables that--along with Mexican agrarian policies, Sonoran economic development, and the vagaries of the transnational livestock industry--affect the livelihoods and political struggles of the Cucurpeños. In an earlier working definition of political ecology, I state:

The exploitation, distribution, and control of natural resources is always mediated by differential relations of power within and among societies. At the same time, however, the resources being exploited impose certain constraints as well -constraints that modify the political force fields emanating from outside the community in question. Peasant societies are neither isolated 'little communities' nor helpless pawns in an international power struggle. On the contrary, they are constantly engaged in a creative dialectic between both local and external forces. (T. Sheridan 1988:xvii).

But how strongly does that dialectic operate when we move beyond a peasant agropastoralist society with a rudimentary technology, and examine commodity production and water control in a modern, rapidly urbanizing society? In a recent history of Arizona (T. Sheridan 1995), I apply the insights of political ecology to the ways in which the social and the natural have interacted for the past 12,000 years. I pay particular attention to the importance of water and how attempts to control it have shaped the political ecology of human societies in the state. I interpret Arizona's past by organizing it into three major phases--Incorporation, Extraction, and Transformation--that mark Arizona's integration into what Immanuel Wallerstein (1974) calls the modern world system. During the first phase--Incorporation--the integration was shifting, tenuous, and incomplete. From the sixteenth to the late nineteenth century, Arizona was a frontier in the most basic sense of the term (D. Weber and S. Rausch 1994). It was not a Turnerian border between civilization and wilderness, or civilization and savagery, because those terms were nothing more than the value judgments of the conquerors (F.J.Turner 1994). Instead, it was contested ground, a place where no one group-tribe, nation-state, or empire -- held uncontested sway until the U.S. and Mexican military won the Indian wars of the 1860s, 1870s, and 1880s. When Geronimo surrendered to General Nelson Miles in 1886, the frontier came to an end. Arizona became politically incorporated into the United States.

That same decade, the phase of Extraction began as the Southern Pacific and Atlantic \& Pacific (later Santa Fe) transcontinental railroads breached Arizona's isolation and bound it to the rest of the nation with iron rails. The railroads allowed capitalists in California, Chicago, the eastern United States, and Western Europe to convert Arizona's natural resources into commodities that could be shipped someplace else for finishing and processing. During the extractive period, the railroads, copper companies, cotton farmers, and ranchers dominated Arizona politics and pitted Mexican and Anglo workers against one another to break the unions and keep wages down. The result was the creation of a class system organized largely along ethnic lines.

By the early twentieth century, however, some people were beginning to view Arizona as more than a bundle of resources to be plundered. Lungers set up tent cities on the outskirts of Phoenix and Tucson to cure their tuberculosis in the desert air. And as the federal government set aside Arizona's most spectacular scenery and archaeological sites as national forests, parks, and monuments, tourists arrived as well. New constituencies were being formed, many of them outside the state. Eventually those constituencies would challenge the miners, ranchers, loggers, and farmers for the right to determine how 
Arizona's natural resources were used, especially on public lands. The third phase--the great Transformation from extractive colony to urban Sunbelt society--had begun.

Not surprisingly, the relationships between natural resources and resource control in Arizona are more complex and less direct than they are in Cucurpe, especially after Arizona became an extractive colony of business interests in the eastern United States and Western Europe. All of Arizona's major extractive industries--ranching, logging, copper mining, and cotton farming--drew on national and global networks of capital in order to respond to national and global demand for particular commodities. A case in point was the extra-long-staple cotton boom between 1916 and 1920. Arizona farmers cultivated very little cotton until World War I, when the British embargoed Egyptian long-staple cotton at a time when the U.S. military desperately needed long-staple fiber for tires and airplane fabric. The federal government and tire companies such as Goodyear, Firestone, and Dunlop therefore turned to the deserts of Arizona, which offered the long, hot, dry growing season long-staple cotton required. By then, the Salt River Project, which had constructed Roosevelt Dam and tamed the Salt River, was already in place and there was a ready supply of cheap, seasonal labor just across the border in Mexico. Global disruption created national demand, and national demand intersected with regional climatic factors, river systems, irrigation networks, and labor patterns to produce Arizona's cotton boom.

The cotton boom, in turn, generated its own momentum as well as its own tensions and contradictions, just as the copper and cattle booms had done forty years earlier. As in Cucurpe, however, each commodity imposed different demands and required different intersections of the global and the local which influenced the social organization of production--and relations of race, class, and gender--in different ways. The levels of organization in Cucurpe and extractive Arizona are very different and difficult to compare. Nonetheless, the basic approach of focusing upon a resource and exploring how it is exploited, distributed, and controlled proved as fruitful in Arizona as it did in Cucurpe. Another definition of political ecology, then, is the historical dialectic that determines how and why certain natural resources are converted into commodities at particular places and times, and how commodity production transforms, and is transformed by, local ecosystems and local societies (see E. Wolf 1982, S. Mintz 1985, and W. Cronon 1991, among others, for analyses of the historical impact of commodification in other areas of the world). Those transformations don't always proceed in the same direction. In some cases, they create disjunctions that require significant reorganizations of production entailing reorganizations of social relationships as well.

Water control represented one such watershed in the political ecology of the American West, including Arizona. The commodification of Arizona was largely carried out by private capital originating outside the state. But water control itself ultimately became the task of the federal government. Until the late nineteenth century, Indian and Hispanic farmers engaged in a creative give-and-take with Arizona rivers but never learned to tame them. The Hohokam may have constructed the largest canal systems in pre-Columbian North America, but they, like the farmers of the Salt River Valley in the 1890s, were vulnerable to both drought and floods.

Beginning in the late 19th century, however, farmers and speculators strove to domesticate rivers across Arizona and the Arid West. The development of those irrigation projects, almost without exception, followed the same trajectory. First came costly and convoluted attempts to finance and construct the projects with private capital. Developers formed canal companies and searched for investors across the United States and Europe. Promotional literature lured thousands of farmers to hallucinatory visions like the Imperial 
Valley of southern California. If private capital could build transcontinental railroads and open great gold, silver, and copper mines, it could reclaim the Great American Desert.

But one by one nature slapped those dreams down. Between 1890 and 1905 in the Salt River Valley, floods alternated with droughts, ruining farmers and canal companies alike. Anywhere from 24 to 33 percent of the acreage in cultivation was abandoned. Banks failed and merchants went broke. Individuals like Carl Hayden acquired their nearmystical belief in the power of big water projects while watching their parents struggle to survive those hard times. Big business had the capital and expertise to work the mines, stock the ranges, and plant the cotton, but it could not afford the massive long-term investment to build the water works. That enterprise required the federal government, which could spread the costs across millions of taxpayers. Without the federal government, there would have been no Salt River Project, no cotton boom, and no urban explosion. That alliance between big business and the federal government is the foundation of Arizona's economy, the very essence of its political ecology.

But the nature of this shifting axis between business and government is easy to misunderstand. The axis revolves around water, and in his provocative Rivers of Empire: Water, Aridity, and the Growth of the American West, historian Donald Worster (1985) resurrects Asian scholar Karl Wittfogel's hydraulic hypothesis to explain it. Wittfogel, a German Marxist who became a rabid anticommunist, argued that aridity was the determining factor in the rise of ancient states in China, Egypt, and Mesopotamia. As more and more people congregated along rivers in desert areas, the need to control floods and provide irrigation water led to the creation of immense water-control systems run by bureaucratic elites. It was a simple and powerful equation: the greater the size of the hydraulic system, the more powerful the elite. Oriental despotism rested upon the magnitude of its dams and canals (K. Wittfogel 1981).

Worster argues that the same can be said about the modern West. In his words:

This American West can best be described as a modern 'hydraulic society,' which is to say, a social order based on the intensive, large-scale manipulation of water and its products in an arid setting. That order is not at all what Thoreau had in mind for the region. What he desired was a society of free association, of self-defining and selfmanaging individuals and communities, more or less equal to one another in power and authority. The hydraulic society of the West, in contrast, is increasingly a coercive, monolithic, and hierarchical system, ruled by a power elite based on the ownership of capital and expertise. (D. Worster 1985:7)

It is a seductive argument, particularly for those who like conspiracies and monoliths. It also shifts responsibility for what has happened in the West from ordinary people to the bureaucrats and their powerful patrons: the agribusinessmen, ranchers, mining executives, and utility companies. According to Worster, Arizona and the West could have been a Jeffersonian democracy of small ranchers and farmers living in harmony with the land. Instead, it is a region of dammed rivers and polluting power plants, of water-guzzling corporate farms and gigantic draglines that scrape away Navajo coal. But ordinary citizens are not to blame for the degradation of the environment or the betrayal of democratic ideals. On the contrary, it is the work of dark forces, of interlocking directorates, of a power elite. In a perversely fatalistic way, Worster's notion is a comfortable one because it absolves most of us of guilt and ignores the messy realities of power. 
Other scholars such as historian Donald Pisani (1989) sharply criticize Worster's model, arguing that he grossly overstates the amount of control exercised by his twoheaded elite. Pisani counters by citing an earlier study by political scientist Arthur Maass and economist Raymond Anderson, who examined irrigation projects in Spain and the American West. According to Maass and Anderson:

The most powerful conclusion that emerges from the case studies is the extent to which water users have controlled their own destinies as farmers, the extent to which the farmers of each community, acting collectively, have determined both the procedures for distributing a limited water supply and the resolution of conflicts with other groups over the development of additional supplies. With important variations to be sure, local control has been the dominant characteristic of irrigation in these regions, regardless of the nationality or religion of the farmers, the epoch, whether formal control is vested in an irrigation community or in higher levels of government, the forms of government at the higher levels, and perhaps even the legal nature of water rights. In this realm of public activity--and one wonders in how many others -formal centralization of authority, where it has occurred, has not meant substantial loss of local control 'de facto' (Maass and Anderson 1988, quoted in D. Pisani 1989:259).

A case in point is the Salt River Project, the Bureau of Reclamation's (BOR) first major experiment of the twentieth century. The federal government built it, but the Salt River Valley Water Users' Association bought it back. The farmers belonging to the association, not federal bureaucrats, ran the organization within seven years of Roosevelt Dam's completion.

But the critique of Worster's monolithic and hierarchical hydraulic society needs to be broadened beyond the institutions directly involved in water. Perhaps a better metaphor for the politics of resource control in Arizona would be that of a feudal society of competing warlords held together by a weak state. Copper companies, railroads, ranchers, farmers, loggers, utility companies, real estate developers, municipal governments--all need water to make their enterprises thrive. And most of them at one time or another have turned to the federal government to supply that water along with many of the other resources they need. But different interest groups have different needs. During the early 1900s, the Salt River Valley Water Users' Association supported the abolition of grazing within the Forest Reserves in order to protect its watershed on the Mogollon Rim. Farmers and ranchers were enemies, not allies, in that struggle. Business, big or otherwise, is not always a monolithic force.

Neither is the federal government. Different interest groups have cultivated, manipulated, or co-opted different agencies of the government to pursue their goals. In the process, different agencies have turned against one another to defend their constituents and grab a greater share of the federal budget. The Corps of Engineers fought the Bureau of Reclamation for the right to build more and more dams. The Bureau of Land Management does not always have the same land-use priorities as the Forest Service, not to mention the Department of Defense. Different agencies of the federal government sue one another over Indian water rights. And there are bitter divisions within agencies themselves. Which of its Multiple Uses are privileged within the Forest Service: logging, grazing, recreation, wildlife? The answer varies from administration to administration.

But even the feudal warlord model implies too much concentrated authority and too much conspiracy. In the final analysis, Arizona has been exploited because of consumer demand. People want housing and automobiles, which require lumber and copper. We 
also want beef, cotton, and citrus. And if we are going to continue to live in desert cities while denying the desert, we need cheap water and cheap energy to keep our lawns green and our buildings cool. The dead rivers and sprawling metropolises are not the result of some conspiratorial power elite but the actions of a monstrous economic democracy of ordinary people who vote with their checkbooks and their feet, cars, and recreational vehicles. As long as people continue to move to Arizona faster than they move out, and as long as they demand inexpensive water and energy once they settle here, utility companies will manipulate government agencies and circumvent existing water rights to provide them. There will be endless negotiations and Byzantine compromises, but no one is going to turn off the tap or throw the switch.

No development in Arizona history better exemplifies this labyrinthine process of negotiation among interest groups and the federal government better than the Central Arizona Project--Arizona's political Holy Grail. The Central Arizona Project was conceived in the 1920s as an agrarian vision to make the desert bloom. By the time Congress finally approved the CAP in 1968, however, Arizona had made the transition from an overwhelmingly rural to an overwhelmingly urban state. Congress appropriated $\$ 1.5$ billion to build the project in 1971, but the Office of Management and Budget impounded those funds until Arizona came up with a workable repayment plan. In response, the state legislature created the Central Arizona Water Conservancy District consisting of Maricopa, Pinal, and Pima counties. The district was given the power to levy an ad valorem property tax to repay the costs of constructing the CAP, but irrigation districts still had to bear the costs of building the canals that would deliver CAP water to individual fields. In 1967, two agricultural economists from the University of Arizona, William Martin and Robert Young, predicted that farmers would never be able to afford CAP water after paying for the delivery systems. They argued instead that farmers should offset the growing costs of groundwater pumping by conserving water and shifting to higher-value crops. It was outright heresy, akin to suggesting that the holy grail was filled with vinegar. Arizona agricultural interests denounced Martin and Young as traitors. Politicians and the press raked them over the coals, accusing Martin of being a paid agent of California. The pressure got so intense that Young eventually left the state (P. Wiley and R. Gottlieb 1982; M. Reisner 1986).

But as CAP costs skyrocketed, Martin and Young's predictions took on the force of prophecy. By 1980, CAP water cost $\$ 30$ an acre-foot more than groundwater before the costs of the distribution systems were even factored into the equation. When they were, the difference was astronomical. In the Maricopa-Stanfield irrigation district alone, Martin and political scientist Helen Ingram discovered that farmers would have to spend an additional $\$ 160$ million to channel CAP water onto their crops. That would tack another $\$ 100$ per acre-foot to the price of CAP water, exceeding the costs of groundwater pumping (\$39 an acre-foot in 1980) by \$91. "In 1980," according to author Marc Reisner (1986:311), "about the only crop you could raise with water that cost $\$ 130$ per acre-foot was marijuana."

The scenario grew even grimmer a decade later. By then, the projected costs of the $\$ 1.5$ billion project had swollen to $\$ 3.6$ billion. In 1991, CAP sold 745,000 acre-feet of water, most of it to farmers. The next year, demand dropped to 421,000 acre-feet and many irrigation districts contemplated bankruptcy despite the interest-free loans that Congress began granting them in 1984. By 1992, farmers were planting only 49 percent of the land eligible for CAP water. And since the government expected farmers to buy 60 to 80 percent of CAP's water during the first thirty years of delivery, their inability to afford 
it threatened the financial viability of the project itself. A study by agricultural economist Paul Wilson of the University of Arizona concluded that property taxes would increase and costs would rise to $\$ 150$ to $\$ 200$ an acre-foot if agricultural demand continued to plunge. The farmers' vision had turned into a fiscal nightmare. True to form, the BOR and the Central Arizona Water Conservancy District began to talk about financially restructuring the project in $1992 .^{2}$

An even greater irony threatened to reverse Arizona history by turning the water over to Native Americans. Anglo and Mexican settlers had diverted water in rivers like the Gila and the Colorado that once irrigated Indian crops. They also had pumped groundwater from aquifers beneath Indian reservations in clear violation of the Winters Doctrine, which evolved out of the Supreme Court decision in 1908 that Indian reservations were entitled to enough water to meet present and future needs. The Winters Doctrine has been ignored more often than enforced, but it has never been revoked after nearly a century of Western water battles (D. McCool 1987).

The Supreme Court decision in 'Arizona v. California'(1963), which reaffirmed Arizona's allotment of Colorado River water under the Colorado River Compact, was another legal victory for Native Americans. 'Arizona v. California' supported 'Winters' and extended the reserved rights principle to other federal lands in addition to Indian reservations. It also demanded quantification of those rights. The result was a formula based upon the amount of water necessary for all "practicably irrigable acres" of reservation land. Because of the decision, five tribes along the lower Colorado were granted nearly a million-acre feet of the Lower Basin's 7.5 million acre-feet allotment under the the Colorado River Compact. Suddenly the fight over the interpretation of the compact and the apportionment of CAP water no longer involved just farmers, municipalities, and seven state governments but Indian reservations as well. Pork-barrel politics dominated the fight to win authorization of the CAP. Complex legal horse trading characterized the negotiation over Indian water rights that followed (F.L. Brown and H. Ingram 1987; T. McGuire 1991, 1992; T. McGuire, W. Lord, and M. Wallace 1993).

The horses that got traded the most were CAP allotments. There were two possible ways of providing Indians with the water they were entitled to under law. One was the strategy pursued by Senator Edward Kennedy, who introduced a bill in 1977 to force the federal government to fulfill its obligations to provide water to five reservations in central Arizona. The bill called for the delivery of 1.2 million acre-feet of water to the Native Americans, primarily by shutting down the Welton-Mohawk Irrigation District east of Yuma and by purchasing farmland with water rights through eminent domain. When they learned of the bill, Arizona farmers and other non-Indian water users rose up in outrage and swatted it down. Taking water from Anglos and giving it back to Indians has never been popular in the state. The political principle behind the San Carlos Project in the 1920s was to find another source of water for the Gila Pimas, not to seize the water of the Anglo farmers upstream.

2. Information on recent developments in the CAP came from the followingnewspaper articles by Enric Volante: "Long-Planned CAP Water FinallyWelcomed to Tucson" (Arizona Daily Star, Oct. 5, 1991); "CAP Costs Likelyto Balloon, UA Report Says" (Arizona Daily Star, Dec. 1, 1992); and "Ex-UAProfessor Predicted CAP Crisis in 1967" (Arizona Daily Star, Dec. 2, 1992). 
That same principle triumphed a year after the Kennedy bill's defeat, when Congress passed the Ak-Chin Act. Ak-Chin is a small (20,000 acre) reservation for Tohono O'odham living around the town of Maricopa. In the 1970s, on behalf of the Ak-Chin community, the Bureau of Indian Affairs (BIA) and the Department of the Interior sued the federal government and surrounding groundwater pumpers. Instead of plunging into a complex legal wrangle that would have dragged on for years, however, the BIA and the Ak Chin tribe agreed to a settlement negotiated by Congress. Congress promised to deliver 85,000 acre-feet of water per year to Ak-Chin. But that water would not be sucked away from farmers in the Stanfield-Maricopa irrigation district. On the contrary, it would come from the CAP, the pot of liquid gold at the end of Arizona's rainbow (T. McGuire 1988, 1992).

CAP water became a crucial part of the 1988 Salt River Pima-Maricopa Indian Community Water Rights Settlement Act as well. The negotiated settlement gave the reservation 122,400 acre feet: 30,000 acre-feet from three nearby irrigation districts through the retirement of farmland, 40,000 acre-feet of stored surface water, 23,000 acrefeet of groundwater, 13,000 acre-feet from the CAP itself, and 20,000 acre-feet of stored Salt River Project water in exchange for an additional 22,000 acre-feet of CAP water purchased from farmers in the Wellton-Mohawk Irrigation District. Once again, the CAP, along with groundwater and the shift from an agricultural to urban landscape, enabled the government to avert a possible water war between Indians and non-Indians (T. McGuire 1992).

The Salt River Act was a good example of an emerging growth industry in Arizona and the West. Rather than lengthy and expensive lawsuits, waterusers could turn to America's most cherished economic ideal--the free market--and simply transfer water rights among themselves. Farmers and Indian reservations could sell water to the relentlessly expanding cities. Everyone could swap water subsidized by the federal government. Politics would be reduced to supply and demand, resource use would be "rationalized," and everybody would prosper and be happy.

Implicit in this horsetrading, however, was the recognition that limits were being reached. CAP had danced in the heads of promoters and developers for more than fifty years before any water flowed down the big canal. Yet all but a few dreamers with visions of water flowing from the Columbia or the Yukon realized that CAP might be the last big water project on Arizona's horizon. So the lawyers, farmers, and city planners had to figure out new ways to allocate the existing water rather than find new sources. The culmination of this realization came in 1980, when the Arizona legislature passed the Groundwater Management Act. At the time, Arizona water users were consuming about 4.8 million acre-feet of water a year, about twice the state's annual renewable supply. Forty percent of that water came from rivers and streams, but sixty percent had to be pumped from hundreds of feet below the ground. Arizonans were mining Pleistocene aquifers, pumping 2.5 million acre-feet more water out of the ground than was recharged through rainfall and runoff. The federal government therefore threatened to hold up the delivery of Arizona's CAP allotment until the state curbed its profligate ways.

Bruce Babbitt was governor then. A lawyer with an intimate knowledge of water law, Babbitt brought together the representatives of the major interest groups--mines, farmers, cities, and water companies--and coaxed, cajoled, and threatened them through a series of marathon meetings that lasted for more than two years. The result was one of the most comprehensive groundwater codes in the nation. The Groundwater Management Act divided the state into four Active Management Areas (AMAs)--Phoenix, Tucson, Prescott, 
and Pinal-- where 80 percent of the population resided and 70 percent of Arizona's water was being consumed. Within the three urban AMAs of Phoenix, Tucson, and Prescott, "safe-yield"--when groundwater withdrawals did not exceed recharge--had to be achieved by the year 2025. Water users had to view groundwater as a renewable resource, not a deposit to be plundered.

And there was more. Because agriculture swallowed about 89 percent of Arizona's water while producing less than 3 percent of the state's personal income, no new acreage could be irrigated within any of the four AMAs. Moreover, new urban development was banned unless there was an "assured water supply." Before a developer could obtain a license to sell subdivided land from the State Real Estate Department, he or she had to demonstrate that the proposed development had enough water to meet its needs for at least 100 years.

After the Groundwater Management Act was passed in 1980, opponents quickly challenged its constitutionality, but the act was upheld by the Arizona Supreme Court, the United States District Court for Arizona, and the United States Court of Appeals for the 9th Circuit. A decade after the law was passed, however, the vultures were circling, waiting for the body to die. The most vocal opponents were developers, who argued that the groundwater code violated that most sacrosanct of Arizona traditions, unrestricted growth. They even challenged the hydrological foundation of the code by citing a report from the state auditor general's office. According to the report, "There is enough water for several hundred years for the Phoenix [area] and for 700 years for Tucson." It went on to say, "The safe-yield goal should be reviewed to determine if it is actually needed, needed by 2025 or later, or if slow depletion of the aquifer is acceptable." (Hardt 1989; Williams 1990).

It was yet another example of the water game, that high-stakes contest that pitted the promoters of endless growth against conservationists and, ultimately, the forces of nature. How much water really flowed down the Colorado? How deep were the aquifers beneath Phoenix and Tucson, and what was the quality of the water locked within those permeable gravels and sand? The numbers varied depending upon the experts you consulted or the ends you wanted to justify. And numbers could be inflated, deflated, or denied. This was not a dispassionate exercise in hydrology. Billions of dollars rode on the outcome.

But what about the role of nature in this struggle? Did the control of Western rivers simply pose an enormous initial challenge that was overcome once and for all by massive dams and regional water compacts? Or does nature keep intruding upon the ongoing negotiation of water control? One complication, among many others, is the problem of the appropriate time frame, i.e. How long will it take to answer that question? In Arizona before the Salt River Project or the Central Arizona Project, natural events such as floods or droughts had an immediate effect upon resource control, just as they do in Cucurpe today. In modern Arizona, on the other hand, technological developments and government subsidies have buffered farmers and city-dwellers against floods, droughts, and other natural disasters. We have subdued the original natural landscape and substituted a cultural landscape of waterworks, transportation networks, capital flows, energy exchanges, and commodity production. That substitution has been so complete that many of us no longer feel that nature is a significant factor in the political and economic development of Arizona or the rest of the West.

But our perception of human omnipotence may be an illusion, or at least an exaggeration. Modern society in the Arid West depends upon perpetual maintenance and investment: investment that continually rises even as it is spread among more and more 
people through tax structures and subsidies. Modern Arizona society is a fragile and volatile creation: one that can never renew itself. Without ceaseless inputs of energy and capital from outside the region, it will wither and die. And the more elaborate Arizona society becomes, the more dependent it is on regional, national, and global forces. With the passage of the North American Free Trade Agreement (NAFTA) in 1993, Arizona will become a gateway between Latin America and the United States. Border cities in Arizona and Sonora will continue to swell, requiring massive investments in transportation systems and public utilities. Trade with Mexico and South America will increase, and even more produce, livestock, and manufactured goods will flow back and forth across the border along Arizona's freeways and railroad tracks. Millions of people will make their way to the border and beyond as Latin America's population continues to outrace its capacity to support them. Latin America's problems and opportunities will become Arizona's problems and opportunities. And as more bodies and industries flee southern California, Arizona will become a major player on the Pacific Rim as well. Competition for water and energy will skyrocket (H. Ingram, N. Laney, and D. Gillilan 1995).

The ultimate loser in this competition will be Arizona agriculture, which consumes 85 to 90 percent of the state's water. As Phoenix becomes a new Los Angeles of five to seven million people, as Tucson turns into a new Phoenix of one to two million inhabitants, and as the border cities of Nogales, Arizona and Nogales, Sonora transform themselves into a new El Paso, Juarez farmers will face intense pressure to sell their water rights to these urban giants. Urban growth, in turn, will generate even greater demand for bedroom communities and vacation homes outside the cities. Rising taxes and rising land prices will tempt more ranchers to sell their patent land to subdividers, especially if urban environmentalists continue to clamor for an end to grazing on public lands. Fewer and fewer people will make a living directly off the land. For those of us who love a wilder, older Arizona, this urban future looks grim. For others, however, it represents jobs, upward mobility, or a chance to make even greater profits off water, energy, land, and construction.

But how long the cities can continue to grow remains unclear. In the short run, there will be plenty of water as long as it can be wrested away from the farmers. In the process, however, much of what attracted people to Arizona will be destroyed. The mountains will still stand, but there will be more hiking clubs, more Boy Scout troops, less of that piercingly beautiful sense of wilderness and isolation many of us crave. National forests will become gigantic city parks like Yosemite or Yellowstone or the South Rim of the Grand Canyon.

Will nature rebel? Will the Colorado break free of its dams as its reservoirs silt up and no longer impound water effectively? Will the costs of maintaining our enormous water and energy networks become prohibitively expensive? Or will we ourselves rebel for spiritual and aesthetic reasons and put a brake on growth? No one really knows. Archaeological evidence from around the world suggests that hydraulic societies eventually overextend themselves and collapse, but none of those societies had access to the technological and financial resources that ours does. It is possible that a neoMalthusian "coming anarchy" of "disease, overpopulation, unprovoked crime, scarcity of resources, refugee migration, the increasing erosion of nation-states and international borders, and the empowerment of private armies, security firms, and international drug cartels" predicted by journalist Robert Kaplan (1994:46) will infiltrate Arizona through its cities and along its border with Sonora. It is also possible that the economies of both Arizona and Sonora will be integrated and energized as predicted by NAFTA supporters. 
Anthropologists alone cannot frame, much less answer, such questions in a sophisticated fashion. What they can do, however, is to examine the dialectics between specific natural resources and commodity production as they work themselves out on the ground, in the sea, or in the atmosphere, in households, corporations, or political institutions, and in the perceptions and values of the people themselves. Anthropologist Thomas McGuire (1996) argues that political ecology must have two defining principles. First, it must pay "simultaneous attention to scale and context in the social and the physical .... The heart of the issue, now, is how to link the 'horizontal' analysis of ecosystem behavior--shorn of its systemic assumptions-- to the 'vertical' analysis of capital, class, and power" (T. McGuire 1996:4-5). Secondly, "Causation across scale, context, the social, and the physical should be empirically determined" (McGuire 1996:5). I agree. Political ecology must be anchored in empirical ethnography and historical research, not 'a priori' assumptions. As anthropologists, our greatest strength--and most significant contribution--will be our critical evaluation of ecological, economic, and political models as they affect real people engaged in making a living off the land, whether they be rancher-farmers in Cucurpe or agribusinessmen, government officials, Indian tribes, and city planners quarreling over water in Arizona.

\section{Bibliography}

Brown, F. Lee and Helen Ingram

1987. Water and Poverty in the Southwest. Tucson: University of Arizona Press.

Crawford, Stanley

1988. Mayordomo: Chronicle of an Acequia in Northern New Mexico, New York: Doubleday.

Cronon, William

1991. Nature's Metropolis: Chicago and the Great West. New York: W.W. Norton \& Company.

Crosby, Alfred

1972. The Columbian Exchange: Biological and Cultural Consequences of 1492. Westport: Greenwood Press.

1986. Ecological Imperialism: The Biological Expansion of Europe, 900-1900. Cambridge: Cambridge University Press.

Hundley, Norris

1975. Water and the West: The Colorado River Compact and the Politics of Water in the American West. Berkeley: University of California Press.

Ingram, Helen, Nancy Laney, and David Gillilan

1995. Divided Waters: Bridging the U.S.-Mexico Border. Tucson: University of Arizona Press.

Kaplan, Robert

1994. The Coming Anarchy. The Atlantic Monthly 273(2):44-76.

Maass, Arthur and Raymond Anderson

1978. ....and the Desert Shall Rejoice: Conflict, Growth, and Justice in Arid Environments. Cambridge, Mass: MIT Press. 
McCool, Daniel

1987. Command of the Waters: Iron Triangles, Federal Water Development, and Indian Water. Berkeley: University of California Press.

McGuire, Thomas

1988. Illusions of Choice in the Indian Irrigation Service: The Ak Chin Project and an Epilogue. Journal of the Southwest 30(2):200-221.

1991. Indian Water Rights Settlements: A Case Study in the Rhetoric of Implementation. American Indian Culture and Research Journal 15(2):139-169.

1992. Getting to Yes in the New West. In State and Reservation: New Perspectives on Federal Indian Policy, edited by George Pierre Castille and Robert Bee, pp. 224-246. Tucson: University of Arizona Press.

1996. Towards a Political Ecology: Observations on the Social Science of Fleet Dynamics and Local Knowledge. Paper prepared for the Symposium "Reinventing Fisheries Management," The Fisheries Centre, University of British Columbia,

February 20-24, 1996.

McGuire, Thomas, William Lord, and Mary Wallace (eds.)

1993. Indian Water in the New West. Tucson: University of Arizona Press.

Meyer, Michael

1984. Water in the Hispanic Southwest: A Social and Legal History, 1550-1850.

Tucson: University of Arizona Press.

Mintz, Sidney

1985. Sweetness and Power: The Place of Sugar in Modern History. New York: Penguin Books.

Netting, Robert McC.

1976. What Alpine Peasants have in Common: Observations on Communal Tenure in a Swiss Village. Human Ecology 4:135-46.

1981. Balancing on an Alp: Ecological Change \& Continuity in a Swiss Mountain Community. Cambridge: Cambridge University Press.

Pisani, Donald

1989. The Irrigation District and the Federal Relationship: Neglected Aspects of Water History. In The Twentieth-Century West: Historical Interpretations, edited by Gerald Nash and Richard Etulain, pp. 257-292. Albuquerque: University of New Mexico Press.

Roseberry, William

1989. Anthropologies and Histories: Essays in Culture, History, and Political Economy. New Brunswick: Rutgers University Press.

Sheridan, Thomas

1988. Where the Dove Calls: The Political Ecology of a Peasant Corporate Community in Northwestern Mexico. Tucson: University of Arizona Press.

1995. Arizona: A History. Tucson: University of Arizona Press.

In Press. La Gente Es Muy Perra: Conflict and Cooperation over Irrigation Water in Cucurpe, Sonora, Mexico. Local Irrigation in World-Wide Perspective, edited by Jonathan Mabry. Tucson: University of Arizona Press.

Sheridan, Thomas and Nancy Parezo (eds.)

In Press. Paths of Life: American Indians of the Southwest and Northern Mexico. Tucson: University of Arizona Press. 
Turner, Frederick Jackson

1994. The Significance of the Frontier in American History. In Where Cultures Meet: Frontiers in Latin American History, edited by David Weber and Jane Rausch. Originally published in 1894.

Wallerstein, Immanuel

1974. The Modern World System I: Capitalist Agriculture and the Origins of the European World-Economy in the Sixteenth Century. New York: Academic Press.

Weber, David and Jane Rausch (eds.)

1994. Where Cultures Meet: Frontiers in Latin American History. Jaguar Books onLatin America No. 6. Wilmington: Scholarly Resources, Inc.

Wiley, Peter and Robert Gottlieb

1982. Empires in the Sun: The Rise of the New American West. Tucson: University of Arizona Press.

Wolf, Eric

1982. Europe and the People Without History. Berkeley: University of California Press.

Worster, Donald

1985. Rivers of Empire: Water, Aridity, and the Growth of the American West. New York: Pantheon Books.

\begin{abstract}
In this paper, I argue that the emerging research strategy of political ecology needs to incorporate an active nature into its analysis of the commodification of natural resources and the politics of resource control. I make reference to earlier work among small rancher-farmers in Cucurpe, Sonora, where the nature of the crucial resources themselves-arable land, grazing land, and irrigation water--determined local agrarian politics as much or more as transnational market demand and Mexican federal agrarian policies. Then I examine water control in Arizona during the past century. I contend that one of the best ways to pursue political ecology is to focus upon the historical dialectic that determines how and why certain natural resources are converted into commodities at particular places and times and how commodity production transforms, and is transformed by, local ecosystems and local societies. Finally, I concur with anthropologist Thomas McGuire that this analysis must be resolutely empirical rather than based upon a priori models or assumptions.

Key Words: culture and nature, water control, political economy, cultural ecology, commodification, Indian water rights, Salt River Project, Central Arizona Project, Colorado River Compact.
\end{abstract}

\title{
Resumé:
}

Dans l'article je constate que la stratégie émergente de recherche de l'écologie politique doit incorporer une nature active dans l'analyse de la commodification des ressources naturelles et la politique de contrôle de ressources. Je mentionne la recherche antérieur parmis petits cultivateurs en Cucurpe, Sonora, où la nature des ressources cruciales elles-mêmes --terre arable, paturages, et eau d'irrigation-- a determiné la 
politique locale agrarienne autant ou plus que la demande du marché transnational et les politiques agrariennes fédérales du Méxique. Ensuite j'étudie le contrôle d'eau en Arizona pendant le siècle passé. Je soutiens que une des meilleurs façons de donner suite à l'écologie politique est de se concentrer sur la dialectique historique qui determine comment et pourquoi certaines ressources naturelles sont converti en produit de base à certains lieus et moments donnés, et comment la production de produit de base transforme, et est l'effet de transmission des ecosystèmes locaux et societés locales. Finalement, je suis d'accord avec l'éthnologue Thomas McGuire que cette analyse doit être résolument empirique plutôt que basé sur modèles ou suppositions a priori.

Mots Clefs:

culture et nature, contrôle d'eau, économie politique, commodification, droits indien à eau, Salt River Project, Central Arizona Project, Colorado River Compact.

\section{Resumen}

En este trabajo, afirmo yo que la estrategia emergente de ecología política tiene que incorporar una naturaleza activa dentro de su análisis de la comodificacíon de los recursos naturales y la política del manejo de los recursos. Refiero a mi estudio de los campesinos de Cucurpe, Sonora, México, donde los recursos necesarios -- milpas, temporales, agostadero, y agua de riego -- determinan la política agraria tanto que el mercado transnacional y los programas agrarios del gobierno federal. Entonces analizo el manejo de agua en Arizona durante este siglo. Considero que una de las maneras mas eficazes de investigar la ecología es enfocar en el dialéctico histórico que determina el proceso de convertir recursos naturales en productos comerciales y las maneras en que la producíon de productos comerciales transforma, y se transforma, ecosistemas locales y sociedades locales. Por fin, concurro con el antropólogo Tomás McGuire que este análisis debe ser rigorosamente empírico.

Palabras Claves:

cultura y naturaleza, control de aguas, economía política, ecología cultural, comodificacíon, derechos indígenas sobre el agua, Salt River Project, Central Arizona Project, Colorado River Compact. 